\title{
NATIONAL INTEREST AND COLLECTIVE SECURITY: ASSESSING THE 'COLLECTIVITY' OF GLOBAL SECURITY IN THE COVID-19 ERA
} Hosea Olayiwola Patrick $^{1 *}$, Ernest Nene Khalema ${ }^{2}$, Rhoda Titilopemi Inioluwa Abiolu ${ }^{3}$, George Mbara ${ }^{4}$

${ }^{1 *, 4}$ Postdoctoral Fellow, University of KwaZulu-Natal, South Africa; ${ }^{2}$ Dean, School of Built Environment and Development Studies, University of KwaZulu-Natal, South Africa; ${ }^{3}$ Postdoctoral Fellow, Durban University of Technology, South Africa.

Email: ${ }^{1 *}$ patrickukzn2016@gmail.com, ${ }^{2}$ khalema@ukzn.ac.za, ${ }^{3}$ abiolurhoda@gmail.com, ${ }^{4}$ mbarag@ukzn.ac.za Article History: Received on $19^{\text {th }}$ February 2021, Revised on $26^{\text {th }}$ April 2021, Published on $29^{\text {th }}$ April 2021

\begin{abstract}
Purpose of the study: The study's rationale is tied to examining the viability of global collective security within a continuously changing arena of national interest of actors. It assesses the basis for global actors' policy responses and actions in the fight against the novel coronavirus (Covid-19).

Methodology: The study uses a secondary data scoping review technique focusing on collective security, national interest, and Covid -19 as the central themes. It utilizes the tenents of human nature, cooperation, and systemic considerations espoused in game theory's stag hunt analysis and Maslow's hierarchy of needs to explore the rationale for state actions in the global arena.

Main findings: The paper confirms that while collective security is essential for global security, its efficacy is dependent on its alignment with states' national interests. Drawing from case observation of global superpowers' responses to Covid-19, the paper argues that the global and 'borderless' impact of Covid-19 serves to buttress the assertion that the integrity of collective security is a function of national interest alignment. In essence, collective security is only 'collective' and effective when state actors' national interests are directly aligned to the pursuance of such security objective(s). The paper concludes that the fight against the Covid-19 pandemic could only be won if global actors shun the narrow gains of national interest and focus on the survival of all through collective policy efforts.
\end{abstract}

Application: The study is relevant as it adds to the body of knowledge and analysis for geopolitics and international relations. It is also a useful prototype in theory testing and analysis within politics and international relations subfields. It is also relevant in the discourse of global public health and human security.

Novelty: The need to assess the methodology and need for collective action in the face of global threats is imperative. Thus, the study serves as an eye-opener and acknowledgment of the declining status of collective security in the face of national interest despite the clamor pre- and post-United nations formation and aim for world peace. Therefore, the global and 'borderless' impact of Covid-19 serves to buttress the assertion that the integrity of collective security is a function of national interest alignment. In essence, collective security is only 'collective' and effective when state actors' national interests are directly in agreement with the pursuance of such security objective(s).

Keywords: Covid-19, Collective Security, Global Actors, National Interest, Pandemic.

\section{INTRODUCTION}

The coronavirus disease (Covid-19), caused by Severe Acute Respiratory Syndrome Coronavirus 2 (Sars-CoV-2), has become one of the foremost global public health issues, and by implication, security concern for policymakers around the world. As the pandemic touches all facets of modern society globally, it becomes increasingly clear that its impacts threaten the world as we know it in terms of its socio-political and economic configurations (Neil, 2020; Wong, 2020; Patrick et al., 2021). The World Health Organisation (WHO) reports that the disease has recorded over 121 million confirmed cases of infections with over 2.6 million deaths as of March 2021 since it was first reported in Wuhan, China, in December 2019 (World Health Organization, 2021). Owing to the nature of the disease and the swiftness of its spread, the WHO declared the virus a public health emergency of international concern on January 30, 2020 (Lee et al., 2020; World Health Organization, 2021). It is plausible to assert that the world is yet to experience a pandemic of this magnitude with a global reach within a short timeframe. The socioeconomic and political impact of this pandemic on every aspect of life and contemporary reality and its impact on global human security is an issue of policy concern (Neil, 2020).

The discourse on security (state-centric and human dimensions) has been an issue of global concern since the formation of man and society (Pahl-Wostl, 2019). The need to avoid all forms of threats while consolidating the chances of survival sits as an innate prerequisite in human relations. Given this, human interactions are motivated by the need to serve self-interest, which is by inference, self-survival. This postulation is true for domestic interactions as it is in the global arena (See Morgenthau, 2014 for the realist's postulation on international politics). As realists would argue, actors within the global arena operate on the premise of competitive self-interest motivated by the need for survival with power as the central currency for interaction. The Covid-19 pandemic poses a peculiar scenario to gauge the viability of this postulation in view of global actors' policy responses and directions in their respective struggle for survival. In the wake of the virus and its spread, states' immediate and subsequent response across the globe was enacting policy actions 
geared towards self-interest and survival. These have included, among others, extended periods of national and sectorial lockdowns, border closures in the bid to curtail the spread of the pandemic, politics of 'blame' and 'counter blame' on cause/origin of the virus, political economy race to vaccine formation, etc. (Vos et al., 2020; Wong et al., 2020). It is no gainsaying that these actions are motivated by power politics and the need to gain comparative advantage over the 'other' within the global arena's comity.

It is pertinent to note that while the Covid-19 pandemic is a global challenge that demands collective global effort, the implications for the socio-economic and political survival for each state and non-state actor are at varying degrees. In that light, the vulnerability of states as well as their adaption will be influenced by their policy orientation, specific ideologies, and practice. While the need to combat this pandemic is an issue of policy and research concern, the need to assess the policy alternatives that state and non-state actors embark on in the face of collective security is paramount. Again, while policymakers and actors are in sync on the fact that the nature of the spread of the disease has the potential to destabilize systems and processes that have defined human existence, states have tended to pursue policies in their national interest in the face of the existential threat posed by Covid-19. This methodology of self-preservation has become a typical protocol by states and non-state actors on any issue within the global arena. Hence, actions and inactions of global actors are thus guided by the strategic socio-political and economic benefit for self rather than the benefit for all as the politics of national interest plays above collective interest. This is exemplified in the continuous politics around greenhouse gas emission and climate change issues, environmental politics, as well as issues around poverty, migration, terrorism, among others. It is, therefore, pertinent to posit that unlike other global issues ravaging the world and the responses of global actors, the most needed global coordinated responses to Covid-19 cannot be handled on the premise of "politics as usual."

Sequel to the above summation, the paper draws jointly on realist theories of human nature, cooperation, and systemic considerations to offer an account of the rationale for the policy response and actions of actors in the international arena in the face of the Covid-19 global pandemic. Using a combination of realist theories postulations from a human nature standpoint (needs approach) and a strategic standpoint (stag hunt), the paper attempts to reinforce the assertion that collective security is a function of national interest alignment. The discourse on collective security is mostly within the domain of state-centric national and international security and threats, especially of defence and military nature. However, we offer a shift in the discourse on collective security to include an alignment of human security and state response to global/public health security threats. Hence, using the global and 'borderless' impact of Covid-19 and the response of global actors, the paper examines the viability of the idea of collective security in the face of actors' national interest in the global arena.

\section{THE RATIONALE OF THE STUDY AND OBJECTIVE}

The study assesses the place of comparative advantage and mutual suspicion motivated by the national interest of actors in the discourse and viability of collective security. The rationale is premised on the need to examine the viability of collective security within the prism of national interest in the global arena. The justification for case study observation underscores the systemic approach (hegemony), the actions, and inactions of global superpowers, specifically the United States, China, Russia, and their allies, as well as organizations (non-state actors) central to the discourse of Covid-19 pandemic.

The ensuing sections discuss the method and theoretical framework for the paper. They present the conceptualization of collective security and national interest, an analysis of selected case studies on actors' policy response in the wake of the Covid-19 pandemic from a systemic approach, and make a case for the need for collective security that supersedes national interest.

\section{METHOD}

The paper is a scoping review of secondary data focusing on collective security, national interest, and Covid -19 as the central themes of the paper ( $\mathrm{Lv}$ et al., 2020). From the discourse of realists' power politics in the international arena (Bell, 2017; $\mathrm{Wu}, 2018$ ), it adopts a confirmatory approach in analyzing the viability of collective security in the face of conflicting national interests of global actors using the global pandemic caused by Covid -19 as a case in point.

\section{DISCUSSION/ ANALYSIS}

\section{Theoretical framework}

The theoretical perspective this paper adopts in assessing the viability of collective security in the era of the Covid-19 global pandemic vis-á-vis national interest is the synthesized assumptions of Maslow's hierarchy of needs and the stag hunt model of game theory. These two views draw discussions from the framework of neorealist complex interdependence theory of international politics. These combined theories aim to appraise global actors' policy actions and direction (state and non-state) amidst the fight to address the imminent global security challenge posed by the Covid-19 pandemic. 
Abraham Maslow's hierarchy of needs theory is based on the "humanistic" approach premised on the assumption that human behavior can be understood by the classification of basic human needs in a hierarchy (Abulof, 2017; Bouzenita \& Boulanouar, 2016; Soni \& Soni, 2016). The theory postulates the idea that human interaction is patterned on specific hierarchical motivation that must be met from the lower order to the top. Higher-order needs are only pursued upon the fulfillment of the preceding lower-order needs in the hierarchy. For Maslow, these needs are arranged from the bottom up as Physiological; Safety; Belongingness and Love; Esteem; Self-Actualization, and Self-Transcendence (Abulof, 2017; Soni \& Soni, 2016). Using this inference, the paramount objective of the state is its survival. Hence, the fulfilment of the lower level needs in terms of its physiological needs (human security), safety, and security are foremost (see

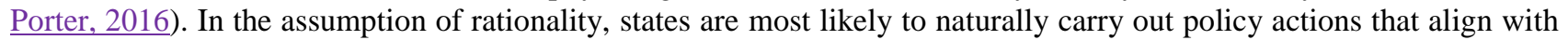
the agenda, prioritizing personal safety and the fulfillment of the lower-order needs (these constitute the essentials of national interest) before considering other higher-order needs which form the rationale for collective security.

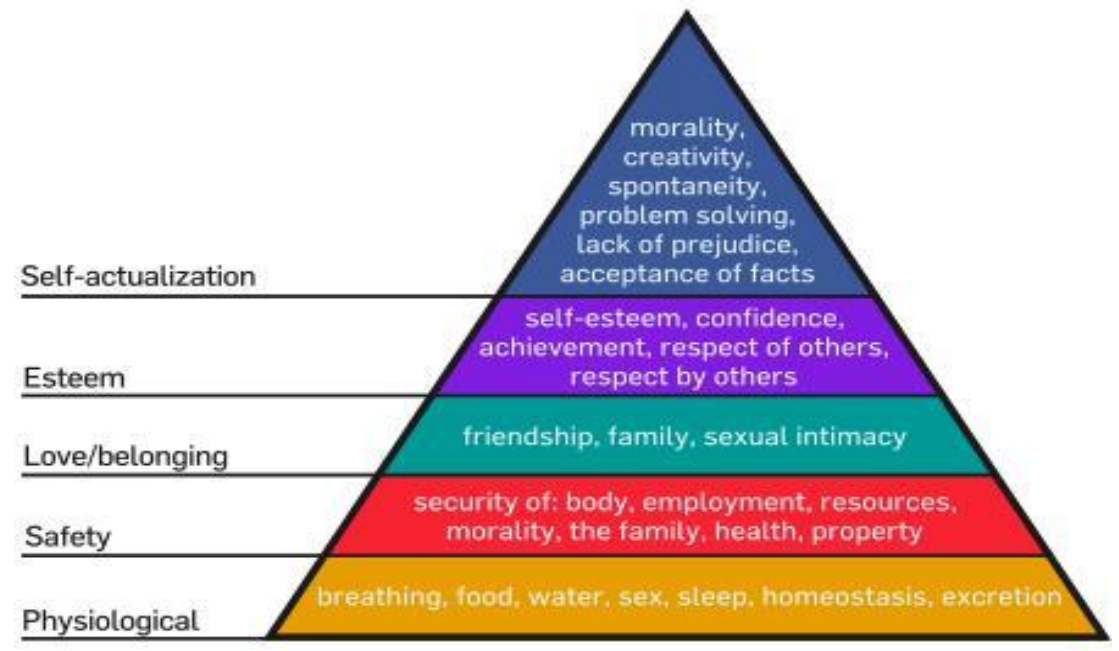

Figure 1: Maslow's hierarchy of needs (Jonas, 2017: 108)

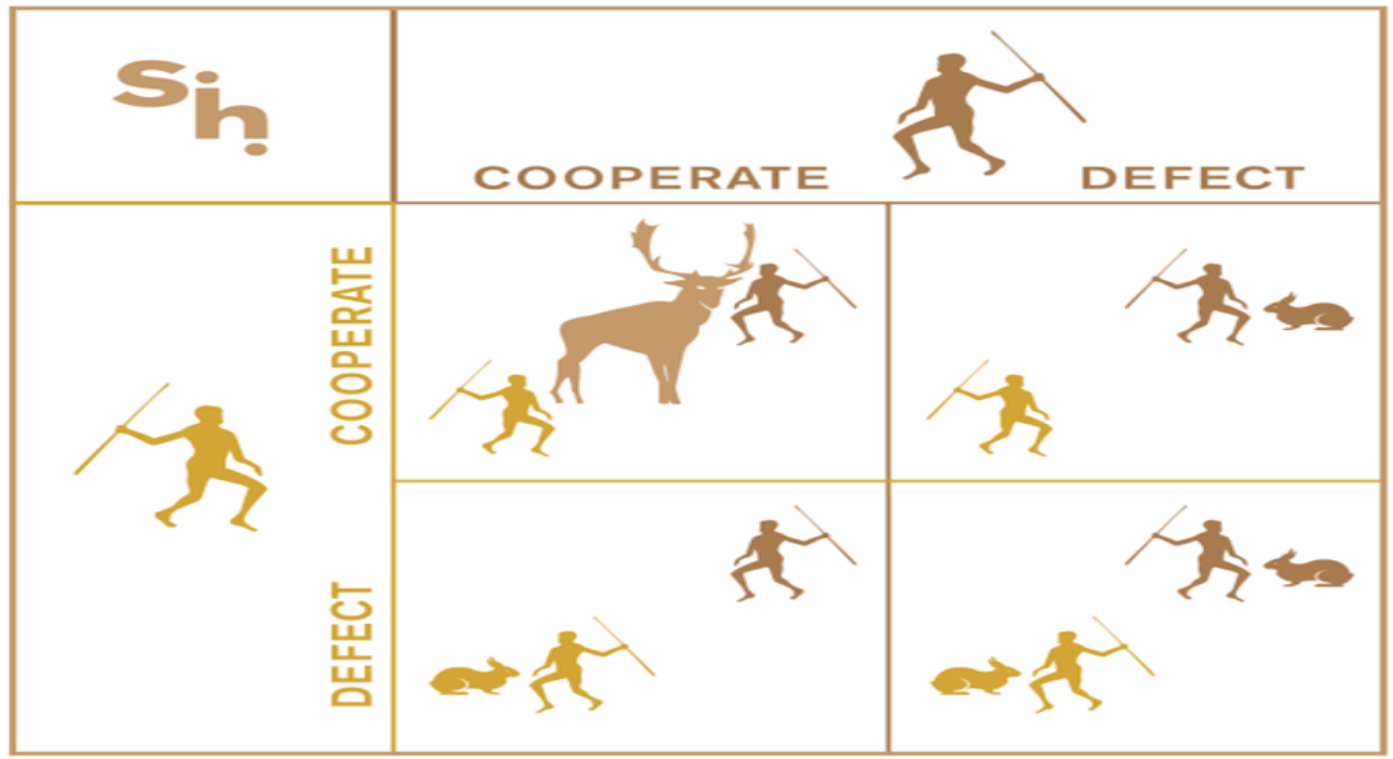

Figure 2: Stag Hunt pictorial depiction (Christopher \& Greg, 2019)

The stag hunt analysis of game theory (also referred to as 'Coordination Game') is hinged on the assumption that actors in a game will achieve maximum result only upon cooperation rather than acting alone (DeCanio \& Fremstad, 2013). The theory projects a strategic standpoint and is premised on the analogy that individuals in a stag hunt can cooperate to hunt a stag or each act alone to hunt a hare. Any hunter's deviation from the collective kill of the big stag to focus on the tiny hare guarantees the failure of the stag hunt for the entire team. In contrast, the deviating hunter gets a hare to the detriment of the entire team. By implication, without cooperation, the stag hunt is guaranteed to fail. The dilemma this creates, firstly, is that all actors are aware that cooperation implies a bigger win for all, and a deviation implies a small win for one at the detriment of all. Secondly, all actors are unaware if anyone of them will deviate, at the detriment of 
all, by going for the smaller catch while factoring that the stag may never come. The theory posits that while players (in this instance, state and non-state actors in the international arena) are assumed to have the unilateral will and are capable of rational choices, the advantage of cooperation outweighs the pursuance of unilateral policy action (DeCanio \& Fremstad, 2013).

The stag hunt model as shown in figure 2 illustrates the policy dilemma of actors, either to act for the collective good of all or in their self-interest within the international arena. As depicted in the stag hunt, actors may pursue individual interests to the detriment of the entire system. This creates a mutual suspicion and the need for faith in the goodwill of other global actors to pursue a collective policy action which is mostly little or non-existent in the international system. Thus, the international system's anarchic nature implies that actors will pursue an interest that will maximize their survival by whatever strategy is available.

In realist tradition, the pursuit of national interest is seen as the guiding rationale for global actors within the international arena (Lebow, 2020; Nuechterlein, 2019). Hence, realists posit that policy actions and directions are guided by actors' self-interests defined within power dynamics in the international arena (Morgenthau, 2014; Rosecrance \& Stein, 2016). Given this, the actions and inactions of actors are geared towards the advancement of comparative advantage over others in their interactions. Within the prism of the complex interdependence theory, these interests align and differ at varying intervals. The theory hereby posits that the international system creates a situation whereby actors become mutually dependent, vulnerable, and sensitive to each other's needs and actions. There is a possibility of conflict in this arrangement despite cooperation and vice versa (Rana, 2015). Within this prism, the challenge which the Covid19 pandemic poses to global security, and especially state actors' response in terms of policy directions and actions, becomes an issue of pertinent concern. The rationale to act alone or cooperatively in the fight to curtail the spread as well as management of the pandemic thus trickles down to policy makers' assessment of the comparative advantage of such action of 'cooperation or sole action' for their national interest.

\section{National interest vs. Collective security: a synopsis}

In understanding the onus of our postulation on the viability of collective security in the face of national interest, the conceptualization of both ideas becomes imperative. This thus provides a background to the analysis of actions and inactions of actors within the global arena in the face of the global public health security challenge posed by the Covid19 pandemic.

National interest is a slippery concept used to describe and prescribe foreign policy by explaining and analyzing foreign policy and justifying or rationalizing state behavior in the global arena. In its simplest terms, national interest connotes state actors' policy objective on how their interest interacts within the international arena (Alsalloum \& Tayie, 2018). The core doctrine of national interest (raison d'état) is conventionally aligned with Machiavelli's 16th-century reflection of statecraft. This views the survival of the state (self-preservation and wellbeing) as the ultimate essence of the state, which must be protected by whatever means necessary (moral and, or immoral) (Navari, 2016; Zartman, 2019). In this sense, national interest connotes the pursuance of state's survival in terms of territorial integrity, security/defense, economic prosperity, and wellbeing, as well as the promotion of state values and ideology within the community of nations (Alsalloum \& Tayie, 2018; Navari, 2016; Zartman, 2019).

Within the discipline of international relations, conceptualizing national interest is problematic as it draws differing perceptions from different schools of thought. The interpretation of what constitutes the 'ultimate objective' of the state (by inference, its national interest) differs according to different schools of thought. In view of this, the objectivists view national interest as the ultimate goal of the state, which is permanent, independent of the policymaker, as well as serves as a rational bipartisan guide for policymakers that can be evaluated, compared, and contrasted. The subjectivists posit that national interest is determined by the changing preference and priority of the policymaker. On the other hand, the constructivists view national interest as a compass that helps to constitute as necessary and legitimize policymakers' actions on behalf of the state (Alsalloum \& Tayie, 2018; Zartman, 2019).

In his speech to the United Kingdom House of Commons, Henry John Temple (1981) captured the essence and permanency of national interest as; thus, "We have no eternal allies, and we have no perpetual enemies. Our interests are eternal and perpetual, and those interests we must follow..." (Murphy, 2016: 17). The implication of this view is buttressed on many fronts by the realists' assumptions of international politics. Firstly, it portrays an international system whereby actors' decision-making and actions within the international arena are independent and motivated by their sole national interest. This, by inference, implies that actors will interact within the international system with the singular agenda of safeguarding their national interest at all costs. Secondly, it also depicts a system whereby alliances are tied only to the singular state's strategic interest. Hence, states have no permanent enemies nor friends. The implication of this arrangement for the international system is the dynamic fluidity in the balance of power, which will be subject to the interest of individual actors regarding prevailing global issues within the international arena. The third implication of Sir Henry's summation for the international system is the strive by each actor within the international arena for strategic advantage fuelled by the need for power accumulation. This supports Hans Morgenthau's postulation of 'power as the currency in the international system.' Hence, he argued that nations would pursue policies that will enhance their power and strategic influence within the international arena (Morgenthau, 2014; Navari, 2016). From this summation, and 
following the neorealist perception of international politics, one could argue that state behavior in the international arena is conditioned by its national interest as a driving force. Within the stag hunt analysis premise, one may argue that the apparent awareness that states will pursue their national interest by whatever means puts all other actors in a dilemma of choice on whether to act in the unity of purpose or pursue singularity of interest. Hence, the pursuance of these differing interests by a multitude of the state is poised to cause instability in the system if not properly maintained. It is, therefore, interesting to observe the dilemma of global actors in the face of the Covid-19 pandemic.

Owing to the anarchic and volatile nature of the global arena, the need for maintaining global security, peace, and stability becomes critical for the survival of the international system. Therefore, the collective force to protect universal security through international cooperation among actors becomes a critical requirement (Lorenz, 2019). Thus, the idea of collective security is seen as the strategic management of international security by a commitment of all actors to jointly work together against aggression or threat to global peace and stability (Karinne, 2017; Tsagourias \& White, 2013). The system of collective security is seen as a utopian policy action and agreement in the international arena aimed at ensuring peaceful existence in the international community by the prohibition of force as well as the neutralization of any form of threat to global peace (Karinne, 2017; Lorenz, 2019; Tsagourias \& White, 2013). The protocol implies a collective action against aggression committed on any member of the 'collective' whereby security concerns all. This implies that an "injury to one is seen as an injury to all" in the sense that collective action is carried out in response to a threat or breach of peace. By this, all actors work cooperatively in neutralizing a security challenge on any member of the collective, as a security threat on anyone is termed a threat to all (Karinne, 2017). To maintain this arrangement, actors are obliged to work cooperatively as a unit for the good of all. It is pertinent to note that this paper is a significant shift in focus on the state-centric militarized notion of collective security to a human security discourse. In this stance, the paper argues that a public health concern (in the sense of the Covid-19 pandemic and its impact on security) is a crucial security concern that requires the collective actions of global actors to quell threats on the survival of each actor.

While the idea of collective security is crucial in maintaining global security, Tsagourias and White (2013) and Lorenz (2019) argued that the notion is utopian in nature. This is because the practicability of collective security is centered on the willingness of members in the collective to subordinate their interest to that of the common good. The reality in most instances is that the viability of collective security is subject to its alignment with the interest of the actors involved, especially the hegemon within the collective. For instance, despite the United Nations (UN) protocol on collective security as captured in Article 2 (4) of the UN charter. ${ }^{1}$ (D’Amato, 2013; Kilovaty, 2015), there are several instances in history where global actors have acted contrary to collective interest/security due to their national interest (Adamthwaite, 2014; Weiss, 2018).

Drawing from the above, it is plausible to argue that the League of Nations as the precursor to the United Nations, collapsed largely due to the institution's failure in enforcing its collective security arrangement, as stated in article 10 of its charter (Zeidler, 2016). The 1923 occupation of the Greek island of Corfu (Phelan, 2017) and the 1935 aggression against Abyssinia in Ethiopia by Italy (Sloane, 2016) were met with no consequence due to the calculation of national interest by member states. The French government claimed the Italian threat to collective security was "a wrong threat at a wrong time, at a wrong border" (Adamthwaite, 2014: 58). As indeed other superpower actors, France's position was mainly on the ground that acting in the collective was not in their strategic national interest. Again, Japan's occupation of China in 1931 (Weiss, 2018) was ignored. Acting in the spirit of collective security against Japan will weaken Japan's power and make Russia a dominant power in the far East. While the collective security principle has become more effective in the post-world war 2 eras, it is still reasonable to posit that the principle seems only efficient when hegemonic interest is aligned in a collective security action.

Within the premise of human security to which the idea of collective security is anchored in this paper, social and economic issues capable of threatening global security are as pivotal as security of a militarized nature. State and nonstate actors' responses (competitive and cordial) to these global security threats are fundamental to maintaining the peace and stability of the international system. As exemplified in the fight on climate change, poverty, terrorism, and meeting with the millennium and sustainable development goals (MDGs and SDGs respectively) among others, the positions were taken by global actors' on these issues are subject to their strategic national interest. The politics that accompany the global collective action needed in the fight against these global security issues, such as climate change as another immediate global threat such as the Covid-19 pandemic, speaks volumes about the degree of viability of collective security argued in this paper. The public health damage being caused globally by Covid-19 and the attendant impact the pandemic has on the socio-political and economic survival of states makes it a security concern.

While Maslow's hierarchy of needs places survival as the first need to be met in the hierarchy of needs, the mutual suspicion that states will act in ways that give them a comparative advantage makes the discourse of mutual collective security in the face of the Covid-19 pandemic problematic. Considering the international system's competitive nature, it is no gainsaying that each actor will strive to pursue interests that places them at a strategic advantage over the other.

\footnotetext{
${ }^{1}$ The United Nations Charter Article 2 (4) states that "... member states shall refrain in their international relations from the threat or use of force against the territorial integrity or political independence of any state..." (D'Amato, 2013;
} Kilovaty, 2015) 
This competitiveness stands the chance of frustrating collective action and security against the concerted global efforts to curtail the Covid-19 pandemic.

\section{Selected case studies of the policy response to Covid-19}

While the Covid-19 pandemic continues to ravage the world in terms of its socio-political and economic implications, policy makers' perception of risk is coined on their assessment of comparative advantage. Therefore, there is no refuting that the need to gain comparative advantage either in the interest of the state or self, as argued in the stag hunt analysis, determines the degree of cooperation or antagonism by policymakers in the international arena. Hence, it is plausible to assert that the interest of global actors influences policy actions and policy directions in the international arena. Within the premise of global politics, the idea of national strategic interest (and by inference, survival) serves as the bedrock for decision-making among world leaders (Nuechterlein, 2019). And as Maslow's theory argued, the need to meet the physiological and safety needs in terms of survival stands far above other higher-order needs like the need for belonging to which collective security falls within. Hence, self-preservation in terms of power dynamics and survival forms the basis for actions and policy decisions actors in the international arena (Lebow, 2020). This by default implies that these actors pursue their survival at whatever cost hereby executing actions and policy decisions that give them a strategic advantage over others in the global arena. The acknowledgment of the fact that each actor would rather act in its selfinterest than the interest of the collective as espoused by the stag hunt analysis of game theory is the constant dilemma of actors within the international system. This inference may explain the ban on international travel and the closing of borders despite the economic and political implications of this policy on the global economy. Another immediate inference will be the national lockdown policy action of most governments around the world despite economic and socio-political concerns in the wake of the swiftness in the spread of the Covid-19 pandemic.

Bearing this in mind, the decision of the Donald Trump-led US government to withdraw its financial contribution to the World Health Organisation (WHO) at a crucial period of the global fight against the Covid-19 pandemic was not outside the confines of the rationale of national interest (Betsy \& Jennifer, 2020). Many will argue that financial contribution is at the prerogative of the donor. However, the implication of the US government's decision amid the century's most significant global health crisis has an enormous negative impact on the concerted global efforts in the fight against the disease, especially for the global South. This policy action can also not be separated entirely from the US and China's hegemonic power struggle on many other socioeconomic and political facades. For instance, China's push to promote itself as a global leader in fighting the Covid-19 pandemic [referred to as the "Global Mask Diplomacy" (Jacinto, 2020; Wong, 2020)] is strategically opposed by the US and its allies. This may explain the 'finger pointing' by the Donald Trump-led US government and its allies towards China as the 'originator' of the disease and accusing China of secrecy in its handling of the pandemic, among other allegations. Trump's conspiracy theory-like postulation of China's plot to ensure his defeat in the 2020 US election is also seen as a motivation for its policy action against the WHO and subsequently the collective global fight on the pandemic (Hans, 2020). While it is easy to treat these actions as sole acts independent of themselves, the thrive for global relevance and hegemonic control would be said to motivate these two world powers' actions in their policy response to the Covid-19 pandemic. From the premise of the theories postulated here, we may argue that the mutual suspicion of these hegemonic powerhouses influences their actions and policy response to the global fight against the Covid-19 pandemic. While each actor (in this case, the US and its allies, China, and WHO, among others) are first concerned about survival, the suspicion that each state would act in its strategic interest harmers negatively on the collective global efforts necessary to curtail the pandemic.

Again, China's policy actions and direction in the face of the Covid-19 pandemic, like the US, have not been outside her strategic national interest. While the mutual role expectations between the two countries (US and China) is becoming progressively unstable due to China's steady rise in power (Shih \& Huang, 2015), the policy actions and directions adopted at this period in history would be crucial in determining the direction of the post-Covid-19 era of world politics. Similarly, the action of the WHO, which the US government cited as a rationale for their decision to halt financial contribution, is also another point to consider. The WHO's hesitance to declare the disease a global pandemic and the difficulty in sanctioning China begs the question as to the rationale for the difficulty in making a stand on China and her role in the spread of the disease (Green, 2020). The WHO's position amidst the global efforts to curtain this global security threat is obviously not independent of protecting its strategic interest as a global actor.

Outside the hegemonic struggle in the face of a need for a concerted global effort, the Covid-19 pandemic also threatens the collective security arrangement of the European Union (EU). The Covid-19 European Union crisis speaks volumes in reinforcing the assertion of national interest alignment as a crucial precursor to the viability of collective security. In the EU, while policymakers agree that the Covid-19 pandemic is a social and economic security challenge that should be addressed collectively, their position in this response varies in terms of their interest and strategic position. For instance, German's swiftness in handling the outbreak and its slow response and near casual approach to the same pandemic in wider Europe (O'Callaghan, 2020) speaks volumes to the importance of national interest in the determination of policy action in the international arena. While some countries in Southern Europe such as France and Italy proposed a Covid-19 marshal plan form of response, whereby "joint aids" and "budgetary transfers" were given to the hardest-hit regions, others in the North were in disagreement with such a plan. Countries like Germany and the Netherlands instead favored an aid system in the form of loans that must be repaid (Hans, 2020). The need for Northern European states to shove 
aside personal interest and assist their southern counterparts, while ensuring a collective action in dealing with the Covid-19 challenge perhaps was what motivated the French President's postulation that "If a part of Europe fall, the whole of Europe will fall." (Hans, 2020; O'Callaghan, 2020). It is pertinent to note that the positions of these states are again in alignment with their individual national interests as the degree of vulnerability to the pandemic varies across Europe.

Again, the Covid-19 pandemic brings to question US-European relations in the face of collective security and national interest. The Trump administration's executive order to place a travel ban on the movements of people from Europe to the US in the wake of the pandemic questioned the idea of collectively. While from a national health care prism, the policy decision of a ban on Europe may be understood, but the same policy action of a ban contravenes the idea of a collective and supports the lookout for 'self-survival. Similarly, the statement by the French government to declare as unacceptable a global pharmaceutical company's decision to reserve the first doses of its Covid-19 vaccine for the US market on the grounds that the said company is based in France shows to a large extent how an actor's view of selfsurvival determines their policy actions and decisions (Bairin \& Cullen, 2020). These actions support Maslow's reasoning that self-survival must come first before the need for 'brotherhood.' In this instance, the survival of France is crucial and sits in the hierarchy of her needs as more valuable than the 'need for belonging' in the international community. Morgenthau's postulation of national interest as a 'power play' in the international arena (Navari, 2016) also holds true in the global efforts against the Covid-19 pandemic. It is plausible to assert that actors within the global arena are in the race to be the first to develop the vaccine for the virus on the premise that the new hegemon in the new world order conditioned by the Covid-19 pandemic will be determined by the control of the vaccine as soft power bargain. This may explain the race by China, US, Russia and other hegemons to discover the world's first vaccine. And as argued in the stag hunt analysis of the game theory, the mutual suspicion of each actor may imply the loss of the 'stag.' In this instance, the continued singularity of actions motivated by the need to gain comparative and strategic advantage, as well as the mutual suspicion that emanates may imply the loss in the battle against the Covid-19 pandemic. These "politics of self" scenarios have proved themselves in other human collective security issues such as the global fight against global warming and climate change, terrorism, human migration and displacement, and hunger, among others. The supposed loss (or near loss) in these global struggles can be pinned on the intricacies of national interests impinging on collective security.

\section{CONCLUSION}

From the foregoing, the policy actions of the US, China, as well as other global leaders to this pandemic shows to a large extent that the politics of self-survival and the need for comparative advantage as against a 'collective' beclouds the collective fight against the pandemic. While this is self-serving, blame-games and power struggle strategies among the world leaders, in a bid to gain comparative advantage, create another crisis within a pandemic as lone efforts by actors in fighting the disease will have minimal impact in a globalized setting. This paper concludes that while the Covid-19 pandemic threatens global security, state policy actions are conditioned by their need for survival. The viability of collective security in its essence is hereby possible only in a situation where the national interests of states are aligned. This invariably means that states and other actors in the international arena view collective security through the narrow lens of their national interests. Therefore, collective security is only 'collective' and effective when actors' national interest is directly aligned to the pursuance of such collective. The Covid-19 pandemic poses a global security challenge that undermines the essence of humanity. Since the survival of all is at stake, to this end, there is an urgent need for global actors to shove away the politics of self and work together in solidarity as one of the global fights against the Covid-19 pandemic will be won. Given this, it is credible to assert that the only way out of the quagmire posed by the Covid-19 pandemic is for actors in the international arena to think as 'we' as against the natural realist postulation of 'self' in international politics. Thus, the fight can only be won if global actors shun the narrow gains of national interest for the survival of all through collective policy efforts in combatting the pandemic.

\section{LIMITATIONS OF THE STUDY}

The study is primarily descriptive in nature. The discourse on Covid-19 and the policy response of global actors is still an emerging research space. Therefore, analysis for this study is mostly inferred based on limited empirical data available on the subject matter as at the period of developing the paper. Hence, the data used were mostly secondary in nature. The study would have benefited more from empirical data.

\section{IMPLICATIONS OF THE STUDY}

The action and inaction of global actors within the global arena can be viewed from different theoretical lenses. The study's rationale is tied to examining the viability of collective security within a continuously changing arena of national interest of actors. The need to assess the methodology and need for collective action in the face of global threats is imperative. Thus, the study serves as an eye-opener and acknowledges the declining status of collective security in the face of national interest despite the clamor pre- and post-United nations formation and aim for world peace. Therefore, the global and 'borderless' impact of Covid-19 serves to buttress the assertion that the integrity of collective security is a function of national interest alignment. In essence, collective security is only 'collective' and effective when state actors' national interests are directly aligned to the pursuance of such security objective(s). 


\section{AUTHOR CONTRIBUTION}

H.O conceptualized the idea, wrote the original draft, reviewed and did the final editing; E.N reviewed the first and final draft and provided validation; R.T.I wrote a section draft, reviewed and edited the final draft, and G.M wrote a section draft. All the authors agreed upon the final draft.

\section{REFERENCES}

1. Abulof, U. (2017). Introduction: Why We Need Maslow in the Twenty-First Century. Society, 54(6), 508-509. https://doi.org/10.1007/s12115-017-0198-6

2. Adamthwaite, A. (2014). Grandeur and Misery: France's bid for power in Europe, 1914-1940. A\&C Black.

3. Alsalloum, K. A., \& Tayie, M. S. (2018). The Present and Future of Kuwaiti-Iranian Relations and Their Influence on the Security of the Arabian Gulf. Asian Social Science, 14(1), 102. https://doi.org/10.5 539/ass.v14n1p102

4. Bairin, P., \& Cullen, S. (2020, May 15). France warns pharmaceutical giant against giving US first doses of Covid-19 vaccine. Cable Network News. https://edition.cnn.com/world/live-news/coronavirus-pandemic-05-1420-intl/h_0e27ae01a67ed737e5c26c5465feccc7?utm_content=2020-05-14T17\%3A30\%3A06\&utm_source=fb CNNi\&utm_term=link\&utm_medium=social\&fbclid=IwAR2kjw-6UECk-D2kszIIcMJYgLDBa1O8cWNVhrX 5_Qmc1MxdB_

5. Bell, D. (2017). Political realism and international relations. Philosophy Compass, 12(2), 1-12. https://doi.org/10.1111/phc3.12403

6. Betsy, K., \& Jennifer, H. (2020, April 15). Trump halts World Health Organization funding over handling of coronavirus outbreak. https://edition.cnn.com/2020/04/14/politics/donald-trump-world-health-organizationfunding-coronavirus/index.html

7. Bouzenita, A. I., \& Boulanouar, A. W. (2016). Maslow's hierarchy of needs: An Islamic critique. Intellectual Discourse, 24(1), 59-81.

8. Christopher, X. J. J., \& Greg, R. (2019). Evolutionary Games Infographics. Evolutionary Games Infographic Project. http://www.christopherxjjensen.com/research/projects/online-cooperative-resource/evolutionary-gameinfographics/

9. D'Amato, A. (2013). The Meaning of Article 2(4) in the U.N. Charter. 2(13), 1-15.

10. DeCanio, S. J., \& Fremstad, A. (2013). Game theory and climate diplomacy. Ecological Economics, 85, 177187. https://doi.org/10.1016/j.ecolecon.2011.04.016

11. Green, M. S. (2020). Did the hesitancy in declaring COVID-19 a pandemic reflect a need to redefine the term? The Lancet, 395(10229), 1034-1035. https://doi.org/10.1016/S0140-6736(20)30630-9

12. Hans, G. (2020, April 25). Macron warns EU could 'collapse' over coronavirus - 'The whole of Europe will fall. Express. https://www.express.co.uk/news/world/1273663/EU-coronavirus-latest-updates-Emmanuel-Mac ron-France-Germany-Italy-bailout

13. Jacinto, L. (2020, May 1). Can the unmasking of China's Covid-19 'mask diplomacy' stem Beijing's global power grab? French24. https://www.france24.com/en/20200501-can-the-unmasking-of-china-s-covid-19-maskdiplomacy-stem-beijing-s-global-power-grab

14. Jonas, J. (2017). | Issn 1728 - 9157 5. Journal of Management \& Admistration, 2, $27-53$.

15. Karinne, C. (2017). The United Nations and collective security. Journal on the Use of Force and International Law, 4(1), 210-222. https://doi.org/10.1080/20531702.2017.1329967.

16. Kilovaty, I. (2015). Rethinking the Prohibition on the Use of Force in the Light of Economic Cyber Warfare: Towards a Broader Scope of Article 2 (4) of the UN Charter. JL \& Cyber Warfare, 2(4).

17. Lebow, R. . (2020). The National Interest. In A Democratic Foreign Policy (pp. 173-211). Palgrave Macmillan, Cham. https://doi.org/10.1007/978-3-030-21519-4_7

18. Lee, T. H., Lin, R. J., Lin, R. T. P., Barkham, T., Rao, P., Leo, Y., \& Lee, T. H. (2020). Testing for SARS-CoV2: Can We Stop at Two? * Outbreak research team members are listed in appendix 1. https://doi.org/ $10.1093 / \mathrm{cid} / \mathrm{ciaa} 459$

19. Lorenz, J. . (2019). Peace, power, and the United Nations: a security system for the twenty-first century. Routledge. https://doi.org/10.4324/9780429301254

20. Lv, M., Luo, X., Estill, J., Liu, Y., Ren, M., Wang, J., Wang, Q., Zhao, S., Wang, X., Yang, S., Feng, X., Li, W., Liu, E., Zhang, X., Wang, L., Zhou, Q., Meng, W., Qi, X., Xun, Y., ... Wang, X. (2020). Coronavirus disease (COVID-19): A scoping review. Eurosurveillance, 25(15), 1-13. https://doi.org/10.2807/15607917.ES.2020.25.15.2000125

21. Morgenthau, H. J. (2014). A realist theory of international politics. Realism Reader, 53.

22. Murphy, M. (2016). The Importance of Alliances for U.S. Security. 2017 Index of U.S. Military Strength: Assessing America's Ability to Provide for the Common Defense, 17-30.

23. Navari, C. (2016). Hans Morgenthau and the National Interest. Ethics and International Affairs, 30(1), 47-54. https://doi.org/10.1017/S089267941500060X

24. Neil, O. (2020, March 31). Case Fatality Rate for COVID-19 Near 1.4\%, Increases with Age. Medscape. https://www.medscape.com/viewarticle/927870 
25. Nuechterlein, D. E. (2019). National interests and presidential leadership: The setting of priorities. Routledge. https://doi.org/10.4324/9780429047459

26. O'Callaghan, L. (2020, April 24). Merkel warned of 'disintegration of Europe' if German leader fails to show EU solidarity. Express. https://www.express.co.uk/news/world/1273453/merkel-news-germany-coronavirus-euitaly-spain-france-economy-euro-eurozone

27. Pahl-Wostl, C. (2019). Governance of the water-energy-food security nexus: A multi-level coordination challenge. Environmental Science and Policy, 92(August 2017), 356-367. https://doi.org/10.1016/j .envsci.2017.07.017

28. Patrick, H. O., Abiolu, R. T., \& Abiolu, O. A. (2021). Reflections on COVID-19 and the viability of curriculum adjustment and delivery options in the South African educational space. Transformation in Higher Education, 6, 9. https://doi.org/10.4102/the.v6i0.101

29. Phelan, M. (2017). Ireland and the Corfu Crisis,. History Ireland, 25(1), 28-30.

30. Porter, P. (2016). Taking uncertainty seriously: Classical realism and national security. European Journal of International Security, 1(2), 239-260. https://doi.org/10.1017/eis.2016.4

31. Rana, W. (2015). Theory of Complex Interdependence: A Comparative Analysis of Realist and Neoliberal Thoughts. International Journal of Business and Social Science, 6(2), 290-297.

32. Rosecrance, R., \& Stein, A. (2016). Beyond realism: the study of grand strategy. ... Bases of Grand ..., 3-21. https://doi.org/10.7591/9781501737701-003

33. Shih, C. -y., \& Huang, C. -c. (2015). China's Quest for Grand Strategy: Power, National Interest, or Relational Security? The Chinese Journal of International Politics, 8(1), 1-26. https://doi.org/10.1093/cjip/pou047

34. Sloane, W. . (2016). The Paradox of Peaceful Co-existence TM: British Dominions' Response to the ItaloAbyssinian crisis 1935-1936. In Collision of Empires (pp. 185-203). Routledge. https://doi.org/10.4324/978 1315572727-9

35. Soni, B., \& Soni, R. (2016). Enhancing Maslow's Hierarchy of Needs for Effective Leadership. Competition Forum, 14(2), 259.

36. Tsagourias, N., \& White, N. D. (2013). Collective Security: theory, law and practice. Cambridge University Press. https://doi.org/10.1017/CBO9781139058506

37. Vos, R., Will, M., \& Laborde, D. (2020). As COVID-19 spreads, no major concern for global food security yet. International Food Policy Research Institute Blog. https://www.africaportal.org/features/covid-19-spreads-nomajor-concern-global-food-security-yet/

38. Weiss, H. (2018). Against Japanese and Italian Imperialism: The Anti-War Campaigns of Communist International Trade Union Organizations , 1931 - 1936. Moving the Social: Journal of Social History and the History of Social Movements, 60, 121-146.

39. Wong, B. (2020, March 25). China’s Mask Diplomacy. The Diplomat. https://thediplomat.com/2020/03/chinasmask-diplomacy/

40. Wong, C. ., Wong, J. ., Tang, E. H., Au, C. H., Lau, K. T., \& Wai, A. K. (2020). Impact of National Containment Measures on Decelerating the Increase in Daily New Cases of COVID-19 in 54 Countries and 4 Epicenters of the Pandemic: Comparative Observational Study. Journal of Medical Internet Research, 22(7), e19904. https://doi.org/10.2196/19904

41. World Health Organization. (2021). Global research on coronavirus disease (COVID-19. World Health Organization. https://www.who.int/emergencies/diseases/novel-coronavirus-2019/global-research-on-novel-co ronavirus-2019-ncov

42. Wu, Z. (2018). Classical geopolitics, realism and the balance of power theory. Journal of Strategic Studies, 41(6), 786-823. https://doi.org/10.1080/01402390.2017.1379398

43. Zartman, I. W. (2019). National Interest and Ideology. In Z. William (Ed.), A Pioneer in Conflict Management and Area Studies. Springer. https://doi.org/10.1007/978-3-030-06079-4_22

44. Zeidler, M. (2016). Hungary and the League of Nations. In E. Dácz, C. Griessler, \& H. Kovács (Eds.), Der Traum vom Frieden-Utopie oder Realität (pp. 187-198). omos Verlagsgesellschaft mbH \& Co. KG. https://doi.org/10.5771/9783845263595-187 